\title{
Learning Foreign Language: Between Globalization and Hegemony in Indonesia
}

\author{
E. Sulyati \\ STKIP Sebelas April Sumedang, Indonesia \\ Email: sulyati@stkip11april.ac.id
}

\begin{abstract}
Implementation of foreign language learning in Indonesia is an effort for the Indonesian people to be able to absorb and follow the development of science and technology in the world, as well as a way to get into the global society. Behind this goal, there is a concern about the infiltration of (Western) values that can erode the identity of foreign language learners as Indonesian. This concern arises because in learning foreign languages contained information about foreign culture (Western) and its cultural values. Western cultural values, if not critically viewed by foreign language teachers and learners, are very likely to change the cultural outlook of learners in Indonesia. Foreign language learning is even suspected of being a Western means of doing hegemony towards the people of Indonesia (East). In this article explained about the situation of foreign language learning in Indonesia, forms of "Western" hegemony against "East" through foreign language learning, Alternative forms of ethnopedagogic and intercultural-based foreign language learning.
\end{abstract}

Keywords: Foreign Language Learning, Hegemony, Ethnopedagogic, Intercultural Learning.

\section{A. INTRODUCTION}

At the beginning of 2013, people in Indonesia, especially the world of education were shocked by the news stating that the Constitutional Court (MK) canceled the existence of International Standard Schools (RSBI) and International Standard Schools (SBI). In its ruling, the panel of judges at the Constitutional Court considered the existence of RSBI / SBI had caused discriminatory treatment in the world of education so that it was considered contrary to the principles of the constitution. (MK: RSBI back to a normal school, 2013). Only children of the rich can get into RSBI because of higher costs than regular schooling. It is common knowledge, that the fees charged to students who will attend RSBI / SBI are very expensive for the size of the majority of people in Indonesia. Its existence is considered to be able to legalize the "cauterization" of education.

The Court emphasized that the existence of RSBI / SBI also has the potential to alienate the world of education with national identity. This is based on the fact of the use of foreign languages namely English at every level of education (Reasons for the MK Disbanding RSBI Schools, 2013). The Constitutional Court's statement raises the question of many parties or some people who have been 'glorifying' learning of English (other foreign languages) namely whether there is a link between learning foreign languages with the potential for reduced identity as the Indonesian nation to students at school? Is this possible? In order to answer that question, we must look at the nature 
and function of language in human life. Language is an entity that is inherent in humans from birth in the world. The existence of this language makes human life cultured.

Language becomes a media developer of the human mind, especially in expressing the reality of all things. Alwasilah (2008: 4) says that a language is a tool for manifesting thoughts about facts and reality represented through sound symbols. Language and mind have a reciprocal relationship, meaning that the form of language used will be influenced by the human mind, on the contrary language can affect the way of human thinking because behind the language of 'standing' culture.

One's identity or identity will be formed through interaction with language and culture. The two are inseparable. For example the role of mother tongue for child development. Alwasilah (2012: 84) states that "socially and culturally mother tongue is a language that is dense culture". When a child learns language from his mother for the first time, he not only learns lingual units that can be used to communicate, but he also learns the wisdom contained in his culture. Through their mother tongue, cultural identity will be formed, including their outlook on life and way of thinking. From this, it can be analogized that the acquisition of a foreign language - in a context at school called learning - can shape (direct) one's cultural identity and way of thinking. Thus the Constitutional Court's concerns about learning a foreign language (English) from beginning Kindergarten - PT could keep students away from their identity as Indonesian people could be understood. Some even worry that through the study of foreign languages, "western colonialism" of culture is carried out latently behind the jargon of globalization and modernization. In this regard, this article will discuss further how the situation of foreign language learning in Indonesia? , Is it true that through education, particularly through foreign language learning, the West can do the hegemony of the East? and what solutions can be offered to strengthen national identity by not eliminating foreign language learning in school?

\section{B. RESUlt AND DisCUSSION}

\section{Situation For Learning Language In Indonesia}

Learning foreign languages in Indonesia has gone through a long history. In the colonial era, foreign languages (such as Dutch as the language of invaders, as well as English and German) had been taught in certain schools, especially in schools for descendants of nobles and Dutch children. Inevitably, mastery of foreign languages among the natives during the Dutch colonial period became a sign of a high or respectable "social class" in society.

Along with the changing times, now foreign language learning is no longer elitist. Everyone can easily learn it. Even English has been introduced to children from an early age. This can be proven by the existence of playgroups or kindergartens who have given English lessons to their students. Likewise at the elementary school level. Alt- 
hough based on Minister of National Education Regulation number 26 of 2006, English began to be taught at the junior high school level. At the level of high school to college, English seems to be an absolute, alongside other subjects such as Indonesian and Mathematics.

Other foreign languages besides English, such as German, French, Japanese, Arabic, and Mandarin, in general, can be learned when students enter high school level. The position of the foreign language can be said to be a compliment. The main thing is that English is recognized as an international language. The background which is the basis for the implementation of foreign language learning at various levels of education can be described as follows. First, most of the science and technology in any field are written in English or other foreign languages, so that the mastery of English or other foreign languages will provide a way for the Indonesian people to absorb the development of science, or spread the developing knowledge in Indonesia. Second, modern society has now become a world community that is no longer confined by distance or time thanks to advances in information technology and transportation. The world community develops into a limitless global society. The mastery of foreign languages will be a door for the Indonesian people to interact in a global society. This aspect of globalization is one of the reasons why English and other foreign languages need to be taught in schools.

These two things also surfaced in one of the rational reasons for the development of the 2013 curriculum which is called an external challenge. In a copy of the Minister of Education and Culture Regulation Appendix No. 69 of 2013 explained: External challenges include but are related to the current of globalization and various issues related to environmental issues, technological and information advancements, the rise of creative and cultural industries, and the development of education at the international level. On that basis, it can be understood if the basic competence of English subjects for junior and senior high schools is to be grateful for the opportunity to learn English as the language of instruction in international communication which is manifested in the spirit of learning. The matter of globalization has actually been alluded to in the previous curriculum. For example, in the Standard Content of English subjects for the SMP/MTs level, it is stated that one of the objectives of organizing these subjects is that students "have an awareness of the nature and importance of English to increase the competitiveness of nations in a global society". (School Principal Training Package: Competency Standards and Basic Competencies, 2011). The same thing is also found in other foreign language subjects such as German and French.

The matter of globalization and science developing in the western world as one of the reasons why foreign languages need to be studied in Indonesia, certainly would not be too questioned if foreign language learning is a single variable that is not accompanied by other variables, both tangible and latent. One important aspect related to this is the fact that language is inherently inherent in the culture of the wearer. In other 
words, the English language studied by students is inherent in the aspects of British (western) culture. Likewise German, French and Japanese. This has become the concern of various parties in Indonesia, that through learning foreign languages students at all levels will prefer to direct their orientation towards foreign languages and cultures. Deprivation from one's own (local) culture which must be a true identity is feared to actually occur.

These concerns are not without foundation. In every educational institution, there is always an inculturation of values, and also cultural acculturation. In the context of foreign language learning, Western cultural acculturation is likely to occur through the teaching and learning process. This will be very dangerous if it is not accompanied by critical awareness by teachers and students. It must be realized that educational institutions are a place of ideological battles. Raymond Williams (in Santoso, 2011) mentions that literary works, philosophy, textbooks (lessons), works of art, schools, and other cultural institutions are hegemony sites, namely where ideological battles take place. At this point, it should be suspected that "the west" uses cultural politics - or soft diplomacy to continue to do hegemony against eastern nations including Indonesia. One way is to use the jargon of globalization and modernization that requires the ability to speak English or other foreign languages. Related to this, it is necessary to explore how western hegemony can take place through the learning of foreign languages.

\section{2. "West" Hegemony On "East" Through Learning Foreign Language}

The concept of hegemony was raised by Antonio Gramsci who investigated how capitalism could continue to dominate the world despite frequent "attacks" from socialist or leftist streams. His thoughts were expressed in a book called The Prison of Notebooks. Gramsci actually did not clearly define what hegemony is. However, hegemony can be understood as the expansion and preservation of the power of the dominant group (the ruling class) over other groups through intellectual, moral and political leadership, and culture. The preservation of this power is accepted "voluntarily" by the groups that are in interest. According to Eriyanto (2001: 104), hegemonic ideology unites and is spread in the practice of life, perceptions, and world views as something that is done and lived voluntarily. Hegemonic power is mostly done not through armed power, but rather more effectively through political power and culture.

Gramsci's thoughts on hegemony later became one of the triggers of Edward Said's critical thinking in the form of postcolonial studies. His thinking has exposed the uninterrupted efforts made by the west to dominate (colonize) the east, as seen in his book Orientalism. Said (1995: 28) offers a rebuttal to the arguments that say that culture and national identity are single and pure entities. By stripping away the notions of "us" and "them" from the empire, Said shows how rotten imperialist assumptions continue to influence Western politics and culture. From this, we can suspect that imperialism in this modern era has changed its face. No longer shows the frightening face with the 
power of weapons, but "friendly face" in the form of invasion of western culture through various means and media, such as films, advertisements, literary works, textbooks, music, and even language learning.

In the realm of linguistics, now known as the linguistic imperialism. English is one of the parties accused of being the perpetrators of imperialism in the linguistic field. No less a figure like Mahatma Gandhi ever worried about the dominance of English. It also became a concern of some European parliamentarians. They are concerned that the power of English over economics, science, and technology could be a threat to the language and culture of the European community in general (Sastrodinomo, 2012). In the International Linguistic Conference organized by ITB, the British Council and the University of Leeds a lawsuit emerged from the Hywel Coleman OBE who argued that the dominance of the English language prevented efforts to maintain linguistic diversity (Kompas, 27 June 2012).

The dominance of English does not only affect other languages which then become subordinate or even marginalized but also impacts on aspects of culture, such as a lack of understanding and respect for one's own culture. From this explanation, we once again found that the Constitutional Court's concern about the loss of national identity due to the use of English in the education world was not far-fetched. The use of English that is too early can potentially uproot a child's identity from its local cultural roots, especially if it is not accompanied by critical thinking by parents and English language teachers. The follow-up question that then arises is, is it possible for students who have become young adults and adults to adopt western cultural values when learning a language does not occur? Or is it possible to be deprived of local cultural roots in adolescence or adulthood? Santoso et al., In 2010 and 2011 conducted studies on the dominance of the west which appeared in foreign language textbooks namely English, German and French. The study was conducted from a postcolonial point of view. The study found several manifestations of western domination. Here are some excerpts from the study results, especially those related to German and French textbooks.

The aspect of Western superiority is one form of postcolonial that appears in the form of images that show that the West (eg Germany and France) has aspects of superiority and modernity compared to the East. Western superiority can be interpreted as a vision of the collective subject of Western intellectuals in marginalizing eastern societies. On page 206 of the German D A1 textbook is the slogan "Made in Germany". This slogan has long been known to indicate that German products are of good quality. On the www.germanoriganilty.com site, it says "..." Made in Germany " is recognized around the world as a label for products of high quality, standards and value ...". No wonder the owners of luxury cars like BMW and Mercedes-Benz later became a symbol of the prestige of their owners. A marker that he is included in the upper-middle class. On page 119 in the French campus textbook, The first picture shows a man and woman when they meet kissing their left and right cheeks. The second picture shows the ar- 
rangement of a dining table that is considered an international scale. These two things are currently being done by many groups of companies from around the world, such as Danone, Carrefour, Nestlé, Philips and Siemens. Western superiority is evident with the presence of these French and European industries in Indonesia. The high enthusiasm of the public in consuming mineral water products such as Aqua which is a license from Danone is very clear. The rapid growth of Carrefour supermarkets in major cities in Indonesia also feels difficult to argue that they have stuck their nails here. The European companies (Germany and France) mentioned above have proven to strengthen the form of Western superiority in Indonesia.

The next form of postcoloniality is mimicry. Mimicry can be understood as forms of imitation, adjustments to ethics and ideal categories of Europe as if they were universal (Ratna, 2008: 452). This is evident in the two images taken from books teaching the language French. In Indonesia, it seemed to be marker modernity for them, even though, effectively, they do not always fit in with the culture of Indonesia. Another form of postcolonialism is what is called bodily politics, a form of behavior to change the identity of one's body by imitating Western body identity. In German textbooks, this aspect is very subtle and is related to one of the worldwide German products, Nivea. Nivea is a cream that is produced to maintain skin clarity for both women and men. Cosmetic products that are considered to make the skin clearer are much in demand by Indonesian women. Someone's motivation to consume it, often because they feel brown skin is not beautiful so they need certain cosmetics that can make their skin more clear/white. During this time it seems a valid assumption that beauty is identical with clear/white skin, sharp nose, and blue eyes. Check out the best-selling soap opera stars, they are artists who generally have mixed blood (Indo).

The aspects presented are only a few examples of how various elements of western culture can seep into the culture in Indonesia and often become a reference for eastern societies. The answer to the question, whether students of adolescence or adulthood like students can be contaminated by western culture becomes clear, that it is very likely to occur if it is not accompanied by a critical attitude and lack of a strong local cultural foundation both by students and foreign language instructors. Some of the examples presented at the same time also show how western culture is embedded in foreign language learning so that it can support the process of Western hegemony towards the East. Aware of that, the West did not hesitate to mobilize all power to open their cultural institutions throughout the world, such as the Goethe-Institut, the British Council, and the IFI-Institut Français d'Indonésie. They also did not hesitate to enter the world of education in high school to introduce their language and culture earlier, as did Germany with its Partner Schule program (abbreviated as PASCH). This program is a form of collaboration between the German government and schools throughout the world which are organizing German language learning. The selected school will receive assistance in the form of human resource development in the form of training for German language 
teachers in Germany, learning tools, and sending outstanding students to Germany. PASCH is just one example. The same thing - although in other forms - is also done by other western countries.

The goal that the German government wants to "shoot" is a long-term goal. This is part of a soft diplomacy strategy. Students who are now learning German in high school will become leaders in Indonesia, at least in the middle and upper classes. They are expected to have an orientation to Germany, such as studying in Germany, buying German products, opening investments for Germany, working together in various fields with Germany and so on. If you pay attention, the same thing is also done by countries that are already very well-established economically, such as America, Britain, France, Japan, Canada and now slowly is China. Then what can be done by the Indonesian people? Should foreign language learning that is suspected to be a suggestion of western hegemony be removed? Of course not. Foreign language learning can still be held side by side with Indonesian or regional language learning. One method offered here is to use ethnopedagogic concepts and language learning based on intercultural approaches.

\section{Etnopedagogy and Learning Foreign Language With Intercultural Insights}

Alwasilah (2012: 118) explains that Ethno pedagogy is an approach in education that relies on the basic values of local communities. Ethno pedagogy views local knowledge or indigenous knowledge as a source of innovation and skills that can be empowered for the welfare of society. With simpler language, Ethno pedagogy is an educational approach that integrates local wisdom in praxis. This local wisdom then becomes a breath for all elements of education involved in it, ranging from the curriculum, teaching and learning process to its evaluation.

Educational praxis that uses etnopedagogical approach is basically an effort to keep students from being uprooted from their cultural roots because they understand well the local wisdom of the community. Ethno pedagogy also provides students with the ability to anticipate the development of a rapidly changing world. An educational praxis with Ethno pedagogy nuances provides students with a strong foundation of local culture.

The praxis of education like this must begin by re-exploring the richness of local culture to find forms of local wisdom. Based on the local wisdom found, the learning process can be designed. In foreign language learning, for example, students can be introduced to folklore (local literature) written in the foreign language being studied. If the people's stories are not found in a foreign language, students can be asked to rewrite folklore into a foreign language. The process of rewriting or reading folklore in a foreign language that is learned must be accompanied by critical analysis to find the positive values contained therein. 
From the didactic and methodical side, the process of teaching and learning of foreign languages always includes an effort to recognize and understand the cultural background of the language being studied. Communicative competencies that are planned to be achieved in such learning will be difficult to realize if students do not know the culture of the foreign language. According to Canale and Swain (in House, 1997) efforts to achieve comprehensive communicative competence will be achieved if students besides mastering linguistic elements also understand the cultural context that is the background of the development of a language. Therefore at certain times, language instructors must explain the cultural aspects of the language they teach.

In such a situation the teacher must be critical because it is often found cultural aspects that accompany a speech utterance not in accordance with local cultural values. As an example of an English phrase that we often hear is "Time is money". If you think about that phrase, it tends to encourage people to use time as efficiently as possible to pursue something material. Don't forget that the phrase came from an industrial country that has a capitalist cultural background. This expression is somewhat different in nuance with, for example, the Javanese proverb that is a lot of origin of the actor (Slowly as long as it is done/achieved). In the saying that contains a message so that we are not in a hurry, patient and careful.

Similarly, the German sentence found in a text in a German textbook reads Sie ist ledig, aber hat ein Kind (He is single, but has one child). The cultural background that can be used to explain this phenomenon is "he is single and adopts a child" or "he is single, but already has children outside of marriage". In the context of German culture, what often happens is the second possibility. Things like this need to be criticized by teachers and students armed with local wisdom. In addition, teachers should not be trapped in attitudes that tend to 'glorify' western culture. In texts in foreign textbooks published in their home countries, discourses have always raised that record the development of the lives of its people, such as technological advancements, the establishment in the economic field, welfare, advanced industries, etc.

An approach in foreign language learning that is currently developing - especially in European countries - is an intercultural approach. This approach has the basis that the actual success of communication that occurs between two communicators from two different cultures is not only determined by the mastery of linguistic aspects, both grammatical and socio-pragmatic structures, but also the ability to capture, understand and have empathy for the culture of its communication partners. Therefore the goal to be achieved is not only communicative competence but also intercultural competence. Intercultural competence is a competency that is owned by someone to interact with people who come from other cultures by holding on the ability to respect their own culture (the self) and empathy for foreign cultures (the other). According to Weimann and Hosch (in Pauldrach, 1992) a global goal of intercultural communication is to contribute to international understanding. Thus foreign language instructors must be able to deliv- 
er their students to be able to understand the foreign culture represented in their language by holding on to understanding their own culture. This is where the compatibility is found between intercultural approaches in foreign language learning with the ethnopedagogic approach.

\section{Conclusion}

The existence of foreign language learning in Indonesia is a necessity. Mastery of foreign languages is needed, for several reasons. First, the mastery of foreign languages is the entrance to enter the global world community (globalization). Second, as a means to absorb the knowledge that is developing in other countries and vice versa is a medium to spread knowledge that is developing in Indonesia to the outside. Both of these reasons are certainly very good to hold. Even so, the Indonesian people must remain critical because learning foreign languages can become a 'vehicle' for the West to carry out hegemony towards Indonesia. In the context of foreign language learning, the possibility of changing the mindset of students learning foreign languages is very possible. Language reflects the thinking patterns of the speaker's community so that when the process of learning a foreign language occurs indirectly there is also a process of confusion with the mindset and culture of the nation whose language is studied. At that time students' cultural insights can change. These changes can be in the form of neglect of one's own culture or excessive worship of the foreign culture.

There are two paths that can be taken as a solution. First, applying the ethnopedagogical approach to learning foreign languages. Through Ethno pedagogy, we will always 'turn to' the local wisdom of the Indonesian people so that fears of deprivation of identity as the Indonesian nation can be eliminated. Second, applying intercultural approaches to learning foreign languages. The intercultural approach aims to develop communicative and intercultural competencies in the learner. Intercultural competence is the ability to empathize with foreign cultures based on one's own culture.

\section{REFERENCES}

1. Alwasilah, A. C. (2008). Philosophy of Language and Education. Bandung: Remaja Rosdakarya.

2. Alwasilah, A. C. (2012). Anyway Engineering Literacy. Bandung: Qibla Main Book.

3. The Court's Reason for Disbanding RSBI School.(2013). Accessed from http://www.tribunnews.com/nasional/2013/01/08/reason-mk-disband-school-rsbi, on October 8, 2013.

4. Eriyanto. (2001). Discourse Analysis, Introduction to Media Text Analysis. Yogyakarta: LkiS Publisher. 
5. House, J. (1997). Zum Erwerbinterculturaleller Competenz im Unterricht des Deutschenals Fremdsprache. Zeitschrift für interculturalellen Fremdsprachenunterricht. Jahrgang, 1(3).

6. Kassim, A. M. (2008). Malay language as a foreign language and the Singapore's education system. GEMA Online ${ }^{\circ}$ Journal of Language Studies, 8(1).

7. MK: RSBI is back to being an ordinary school (2013). Merdeka.com. accessed from http://www.merdeka.com/perEvents/mk-rsbi-back-to-school-regular.html on February $9,2013$.

8. School Principal Training Package: Competency Standards and Basic Competence.

9. Pauldrach, A. (1992). Eine unendliche Geschichte: Anmerkungen zur Situation der Landeskunde in denrener Jahren. Fremdsprache Deutsch-Zeitschrift für den Praxis des Deutschunterrichts: Landeskunde.

10. Phillipson, R. (2004). English in globalization: Three approaches. Journal of Language, Identity, and Education, 3(1), 73-84.

11. Regulation of the Minister of National Education, No. 26, 2006.

12. Ratna, N. K. (2008). Indonesian Postcolonialism, Literary Relevance. Yogyakarta: Pustaka Pelajar.

13. Said, E. (1995). Culture and Power: Dismantling the Myth of Western Hegemony. Bandung: Mizan.

14. Said, E. (1994). Orientalism. Bandung: Library Publisher

15. Regulation of the Minister of Education and Culture, Number 69 of 2013 concerning the Basic Framework and Curriculum Structure of Senior High Schools/Madrasah Aliyah.

16. Santoso, I., Nurhadi, Swandayani, D., \& Nurhayati, A. (2011). The Latest Forms of Western Domination in Indonesia: Postcolonial Study of University Textbooks, Literary Works, and Western Thought. Stranas Grant Research Report, DP2M Dikti.

17. Sastrodinomo, K. (2012). Against English Domination. Quoted from Kompas, 27 April 2012.

18. Sugiharto, S. (2013). Rethinking globalization, reclaiming the local: A post-colonial perspective of English language education in Indonesia. The Indonesian Quarter$l y, 41(3), 148-166$.

19. Yusny, R. (2013). ELT in Indonesian context: Issues and challenges. Englisia Journal, 1(1), 81-99. 